\title{
State of the art i gnosis-forskningen
}

\author{
Hvor står drøftelsen af gnosticisme og gnosis aktuelt?
}

\author{
Review-artikel
}

ANDERS KLOSTERGAARD PETERSEN

\begin{abstract}
ENGLISH ABSTRACT: The present article provides the reader with a state of the art over-view of the discussion of Gnosticism and gnosis during the past 15 years of scholarship. Brakke's recently published book, The Gnostics. Myth, Ritual, and Diversity in Early Christianity, represents an important contribution to this discussion. The book is lauded for its attempt to move beyond the conceptual eliminativism characteristic of the works of Michael Williams and Karen King. Although I am critical towards the attempt from an emic perspective to identify gnosis with Sethian forms of religiosity I acknowledge the scholarly progress when compared with the works of Williams and King. Contrary to Brakke, I propose to use the category of gnosis at the etic level only. Such an understanding will enable us to see both Valentinian and Sethian forms of religiosity not only as different manifestations of the same phenomenon but also as closely related to phenomena belonging to what we are wont to conceive of as more mainstream forms of early Christianity.
\end{abstract}

DANSK RESUMÉ: I forlængelse af David Brakkes nyligt udgivne og for gnosis-forskningen meget væsentlige bog, The Gnostics. Myth, Ritual, and Diversity in Early Christianity, præsenterer jeg en state of the art-artikel $i$ forhold til de sidste 15 arrs drøftelse af emnet. Brakke fremhæves for hans forsøg på at komme hinsides den begrebseliminativisme, som både Michael Williams' og Karen Kings arbejder repræsenterer. Skønt jeg forholder mig kritisk til Bentley Laytons og Brakkes forsøg på på et emic niveau at identificere gnosis med sethiansk gnosis, anerkender jeg, at der er tale om en forbedring i forhold til Williams og King. Omvendt argumenterer jeg for alene at an- 
vende gnosis-kategorien på et etic niveau, som sætter os $i$ stand til at se både valentinianisme og sethianisme som ikke alene forskellige manifestationer af samme frnomen, men også som nært beslægtet med fænomener inden for det, vi traditionelt forstår som mere mainstream former for kristendom.

Keywords: Gnosticism, gnostic, orthodoxy, heresy, sethianism, valentinianism, etic, emic.

David Brakke, The Gnostics. Myth, Ritual, and Diversity in Early Christianity, Harvard UP, Cambridge, Mass., og London 2010. 164 sider, £ 22,95.

David Brakke, som er professor i religionsvidenskab ved Indiana University (en af de største afdelinger for faget i USA), har med sin bog om gnostikerne skrevet et væsentligt bidrag til den moderne gnosis-forskning, som for alvor tog sin begyndelse for 15 år siden med udgivelsen af Michael Williams' Rethinking "Gnosticism": An Argument for Dismantling a Dubious Category. Da der er tale om en central udgivelse inden for felterne klassisk religionshistorie i almindelighed og tidlig jødedom, kristendom og gnosis i særdeleshed, fortjener bogen en mere udførlig drøftelse, som samtidig kan give RvTs læserskare en fornemmelse af state of the art inden for feltet gnosis og gnosticisme. ${ }^{1}$

Der er sket meget i gnosis-forskningen i løbet af de forgangne 15 år. Vi er langt fra Messina-konferencens jagt på en komplet og fuldkommen gnosticisme-definition og historisk forklaring på gnosticismens fremkomst. ${ }^{2}$ I 1966 afholdtes i den italienske by Messina en stort anlagt international konference organiseret og ledet af italiensk religionshistories i dag afdøde nestor, Ugo Bianchi. Konferencens mål var at nå frem til en endelig og fuldstændig definition af gnosticisme og, subsidiært, en omfattende historisk forklaring på fænomenets fremkomst. Det lykkedes - måske ikke helt overraskende - ikke at nå frem til en konklusion, som alle kunne samles om; men Bianchi forsøgte i sit indledende bidrag til den efterfølgende konferenceudgivelse at levere en tentativ definition, som flertallet af konferencens deltagere støttede, ligesom han søgte at give en omfattende historisk forklaring på gnosticismens oprindelse. Først forstod man gnosis som et bredt religionshistorisk fænomen, der betegner viden forbeholdt en udvalgt gruppe. Det findes på tværs af tid og sted i alle religioner. Dernæst define-

1 En glimrende forskningshistorisk oversigt findes i Antti Marjanen, "What Is Gnosticism? From Pastorals to Rudolph", i samme (ed.), Was There a Gnostic Religion?, Publications of the Finnish Exegetical Society 87, Helsinki, Finnish Exegetical Society og Göttingen, Vandenhoeck \& Ruprecht 2005, s. 1-53. På dansk grund findes en omfattende diskussion af nyere gnosisforskning samt Judasevangeliets betydning for forståelsen af gnosis i A. K. Petersen, J. Hyldahl \& E. Thomasson, eds., Mellem venner og fjender. En folkebog om Judasevangeliet, gnosis og tidlig kristendom, Antikken og kristendommen 6, Anis, København 2008.

2 U. Bianchi, ed., Le Origini dello Gnosticismo: Colloquio di Messina, 13-18 Aprile 1966, Numen xii, Brill, Leiden 1967. 
rede man gnosticisme mere snævert i forlængelse af de systemer, som kendtes som gnostiske fra det andet årh. e.v.t., ud fra to parametre. For det første består gnosticisme af forestillingen om en guddommelig gnist i menneskeheden, som hidrører fra den guddommelige sfære, men som gennem et fald er kommet ind i skæbnens, fødslens og dødens verden, og som derfor har behov for på ny at vækkes af dens guddommelige modpart. For det andet gælder det for disse gnostiske systemer, at de i sammenligning med andre forestillinger om det guddommeliges devolution (dvs. overdragelse af hjemfaldet gods til en andens besiddelse) ontologisk hviler på en tanke om det guddommeliges nedadstigende bevægelse. Dernæst geråder det guddommeliges periferi - villet eller ej - i krise og skaber verden, som den efterfølgende ikke kan opgive; for derved ville det guddommelige ikke kunne generobre den mistede pneuma. Det er, hævder Bianchi, en dualistisk forestilling på monistisk grund udtrykt i dobbeltbevægelsen, devolution og reintegration (s. xxvii m. italiensk, fransk og tysk paralleloversættelse s. xxi.xxiv.xxx). Denne tanke om overførsel udelukkede for Bianchi og en lang række andre af konferencens deltagere, at gnosticisme kunne forstås som samme historiske og religiøse type som jødedom, nytestamentlig kristendom eller som senere former for mainstream-kristendom. Gnosticismen skulle derfor hverken forbindes med jødedom eller kristendom, men snarere med Upanishade-litteraturen eller middelalderens katharer (s. xxviii m. italiensk, fransk og tysk paralleloversættelse s. xxii.xxv.xxxi).

En tilsvarende bred forståelse af gnosticisme blev fremført i den tyske religionshistoriker Kurt Rudolphs indflydelsesrige bog om gnosis fra 1977.3 Også hos Rudolph får gnosticisme karakter af en religionstype, der lader sig identificere på tværs af både lang tid og vidtstrakt rum. Hos Rudolph blev fænomenet nærmest identisk med en hvilken som helst dualistisk og verdensforsagende religion, som med løfte om frelse lovede de indsigtsfulde udfrielse fra den jordiske verden (s. 7.63-76). Derfor kunne betegnelsen hos Rudolph også indbefatte så forskellige religioner som manikæisme, mandæisme samt bogomiler og katharer, som Rudolph betegner neognostiske eller neomanikæiske, foruden de grupper, der traditionelt blev regnet for gnostiske. Elaine Pagels mere populære, men ikke mindst i kraft af sin omfattende læserskare ligeledes betydningsfulde bog fra 1979 om gnostikerne koncentrerede sig om at diskutere relationen mellem, hvad hun betegnede ortodoks kristendom og kristne gnostikere. ${ }^{4}$ Fælles for Bianchi, Rudolph og Pagels var, at gnostikerne udgjorde jødedommens og kristendommens andethed og var i modsætning til de to først og fremmest karakteriseret ved verdensforsagelse og et negativt syn på skabelse og kosmos.

Hele denne forskningstradition kom imidlertid til en brat afslutning i 1996, da Michael Williams med den ovenfor omtalte bog foretog en radikal dekonstruktion af

3 K. Rudolph, Die Gnosis. Wesen und Geschichte einer spätantiken Religion, UTB Taschenbücher 1577, Vandenhoeck \& Ruprecht, Göttingen 1977, som siden er udkommet i yderligere to reviderede versioner og utallige oplag. Bogen udkom i 1983 på engelsk og fik også her nærmest kanonisk status som den væsentligste introduktionsbog til gnosticisme, se K. Rudolph, Gnosis: The Nature and History of Gnosticism, Harper \& row, San Francisco 1983.

4 E. Pagels, The Gnostics, Random House, New York 1979. 
selve kategorien gnosticisme. ${ }^{5}$ Det bærende synspunkt i hans bog var, at de tekster og religiøse strømninger, man traditionelt havde henregnet til gnosticisme, indbyrdes repræsenterer en sådan mangfoldighed af synspunkter, at de dårligt lader sig placere i en og samme historiske kategori. Tilsvarende dokumenterede han, hvordan en lang række af de forestillinger, som i gnosis-forskningen havde fået karakter af hævdvundne sandheder om gnostisk religion, byggede på misforståelser, fordrejninger og grovkornede generaliseringer. Williams foretog imidlertid ikke nogen total dekonstruktion, men medgav, at flere af de tekster og bevægelser, man traditionelt havde betegnet gnostiske, rent faktisk delte en række fællestræk. Han foreslog derfor i stedet for at kategorisere dem som 'bibelsk demiurgiske traditioner', hvormed han ønskede at betegne de bevægelser og traditioner, "that ascribe the creation and management of the cosmos to some lower entity or entities, distinct from the highest God" (s. 51). ${ }^{6}$ Samtidig bragte Williams gnosis-forskningen videre ved i en helt anden grad end tidligere sprogligt at tematisere forskellige 'gnostiske' strømninger gennem den eksplicitte omtale af dem som fx valentinianisme og sethianisme, ligesom han - blandt andet fremhævet gennem kategorien bibelsk demiurgiske traditioner - i modsætning til Messina-bindet, Rudolph og Pagels betonede gnosis som religionshistorisk hjemhørende i tidlig jødedom og kristendom (s. 231-34). Jeg har selv været stærkt påvirket af Williams, men også klandret ham for ikke i tilstrækkelig grad at løsrive sig fra hæresiologernes måde at kortlægge verden på (Petersen 2008, 242-45).

Få år efter udgivelsen af Williams' bog fulgte en anden skelsættende bog om gnosis, nemlig Harvard-professoren Karen Kings What Is Gnosticism? fra 2003. ${ }^{7}$ De to bøger til sammen indledte en ny fase i gnosis-forskningen, som vi fortsat befinder os i. King delte i vid udstrækning Williams' ærinde; men hun var endnu mere radikal end Williams, fordi hun en gang for alle ønskede at gøre op med gnosis-kategorien, ligesom hun til forskel fra Williams helt anderledes fokuserede på de ideologiske dimensioner i forskningsdiskussionen. I modsætning til Williams tilbød hun derfor heller ikke nogen alternativ religionshistorisk kategori, men hævdede emfatisk, at den moderne gnosticisme-kategori i sidste instans er en videreførelse af hæresiologernes ærinde, dvs. de kirkefædre der som Irenæus (ca. 115-202), Hippolyt (ca. 170-236), Tertullian (ca. 160-225), Origenes (ca. 185-255), Pseudo-Tertullian (3. årh.) og Epifanios af Salamis (ca. 315-403) polemiserede mod gnostikerne. King fik dermed sagt, at forskningen i modsætning til egen selvforståelse snarere end at være analytisk distanceret

5 M. A. Williams, Rethinking "Gnosticism". An Argument for Dismantling a Dubious Category, Princeton UP, Princeton 1996. Williams har siden haft lejlighed til at uddybe sin forståelse og reagere på noget af den kritik, som har været rettet mod bogen, i A. Marjanen, ed., Was There a Gnostic Religion?, Publications of the Finnish Exegetical Society 87, Finnish Exegetical Society, Helsinki and Vandenhoeck \& Ruprecht, Göttingen 2005, 55-79.

6 Williams 2005, s. 78, præciserer brugen af 'demiurgisk bibelsk': "Demiurgical" for me is not just another label for the same religion others have called "Gnosticism." It is a heuristic category entailing a feature that I do think is worthy of study across several traditions, where its function may nevertheless be somewhat diverse."

7 K. King, What Is Gnosticism?, Harvard UP, Cambridge, Mass. and London 2003. 
i forhold til sit studieobjekt i virkeligheden var ideologisk budbringer for en bestemt røst i den tidlige kristendom, nemlig hæresiologerne og bispekirken. Kings bog var i denne sammenhæng del af en bølge, som forsøgte at åbne studiet af tidlig kristendom på ny gennem pointeringen af, hvor åbent det felt, vi i dag betegner tidlig kristendom, var i det andet århundrede og helt frem til begyndelsen af det fjerde århundrede, hvor en bestemt type kristendom med kejserlig opbakning satte sig igennem. Det er om end ikke samme så dog en beslægtet strømning inden for samme forskningstradition, der tilsvarende har understreget, hvordan også den tidlige Kristusbevægelse var en uløselig del af jødedommen og for store gruppers vedkommende fortsatte med at være del af jødedommen flere hundrede år frem i tid. Således er også dateringen af den såkaldte partings of the ways mellem jødedom og kristendom fremrykket til det femte århundrede e.v.t., hvor man definitivt kan tale om kristendom som en i forhold til jødedommen uafhængig og selvstændig religion. ${ }^{8}$

Pointeringen af mangfoldighed og uafklarethed er prægnant i Kings bog. Frem for som tidligere at forstå den tidlige kristendom i lyset af senere tiders sondringer mellem ortodoksi og hæresi eller som det hyppigt formuleres, når skelnen tilbageprojiceres til det andet århundrede, mellem proto-ortodoksi og hæresi, betonede King, hvordan disse differentieringer forudsætter en institutionalisering og hegemonisering af en type kristendom, som dårligt kan tænkes forud for tidligst kejser Konstantin. Kings bog var ligeledes del af en særligt amerikansk båret 'politisk korrekthed' i forskningen, hvor historikeren gennem fremhævelsen af mangfoldigheden i tidlig kristendom skaber rum for marginaliserede røster i moderne former for kristendom: Historikerens opgave består ifølge King således ikke i at “... destroy tradition but to open up space for alternative or marginalized voices to be heard within it. A fuller historical portrait of religious piety can enrich the funds of religious tradition, providing more complex theological resources to attend to the complex isssues of our own day" (s. 246).

Over for disse forsøg på at afmontere gnosticisme-begrebet som religionshistorisk kategori har der efterfølgende været, måske ikke overraskende, en række modsatrettede forsøg på at rehabilitere betegnelsen. Christoph Markschies fx, som i dag hører til en af Tysklands mest prominente gnosis-forskere, har argumenteret for en typologisk forståelse af gnosis, der indbefatter otte forskellige kendetegn - meget lig flere af de kriterier, som indgik i Messina-bindets, Rudolphs og Pagels forståelser. Gnosis er hos Markschies imidlertid ikke en bestemt religion, men en række forskellige tendenser som fx valentinianisme og sethianisme, der først i manikæismen kommer til udtryk som egentlig selvstændig religion. ${ }^{9}$ Den mest prominente repræsentant for den typologiske tilgang er imidlertid Birger Pearson fra Claremont-instituttet i Californien. Han

8 Se hertil min artikel "At the End of the Road - Reflections on a Popular Scholarly Metaphor", i: J. Ådna, ed., The Formation of the Early Church, WUNT 183, Mohr-Siebeck, Tübingen 2005, 45-72, og ikke mindst samlebindet A. H. Becker og A. Y. Reed, eds., The Ways that Never Parted, TSAJ 95, Mohr-Siebeck, Tübingen 2003.

9 C. Markschies, Gnosis. An Introduction, T\&T Clark, London/New York 2003 (engelsk oversættelse af tysk orginal fra 2001), 21-23. 
argumenterer i modsætning til de fleste andre inden for forskningen for, at gnosis de facto var en selvstændig form for religion i antikken. ${ }^{10} \mathrm{Ud}$ fra Ninians Smarts religionsdefinition eller måske snarere religionstypologi analyserer Pearson flere koptiske tekster fra Nag Hammadi med særlig vægt på Johannesapokryfen og når frem til, at teksterne rummer alle Smarts syv elementer og derfor i sagens natur må have udgjort en religion. ${ }^{11}$ Det er ikke vanskeligt at kritisere Pearsons forståelse, som David Brakke i lighed med andre da også gør. At flere af Nag Hammadi-teksterne efterlever Smarts syv kriterier for en religion, viser, at de er religiøse; men det dokumenterer selvsagt ikke, at der er tale om en selvstændig religion. Her er der tale om en problematisk sammenblanding af analytiske niveauer.

Det sidste eksempel, jeg i denne forbindelse vil nævne, er min finske kollega Antti Marjanen som repræsenterer en afart af den typologiske tilgang. I modsætning til de øvrige repræsentanter for denne forståelse er Marjanen helt på det rene med, at relationen mellem typologi og empiri er af epistemisk karakter. Han ved godt, at typologien alene er en analytisk konstruktion, der ikke står i et 1:1-forhold til den historiske empiri, som typologien forsøger at indfange. ${ }^{12}$ Marjanens typologi hører også til en af de mest enkle og derfor mest anvendelige, idet han alene anfører to kriterier for tilhørsforholdet til kategorien gnosis. Det første er, at for at kunne klassificeres som gnostisk religiøsitet skal teksten indeholde forestillinger om en (eller flere) ond(e) eller uvidende skabergud(er), som er forskellig(e) fra den højeste guddom. Andet kriterium drejer sig om, at den menneskelige sjæl eller ånd hidrører fra den transcendente verden, og at sjælen eller ånden gennem en bevidstgørelse om sit guddommelige ophav har mulighed for at vende tilbage til sit egentlige hjem (s. 194). Marjanens forståelse af fænomenet er også historisk mere snæver end de øvrige repræsentanter for den typologiske tilgang, fordi han indskrænker fænomenet til primært at dreje sig om valentinianisme og sethianisme (s. 195.203).

En lidt anderledes tilgang, som i denne sammenhæng er væsentlig, fordi Brakkes bog lægger sig i forlængelse af den, er Bentley Laytons gnosis-rekonstruktion. Layton, som også var Brakkes lærer, har under påvirkning af en kort, men betydningsfuld artikel af tyskeren Hans Martin Schenke fra 1974 gjort sig til talsmand for et opgør med den typologiske tilgang. ${ }^{13}$ I lighed med Schenke har Layton argumenteret for at forstå gnostiker som social kategori, dvs. at der de facto var nogle, som forstod sig selv som gnostikere. Grundlæggende for denne tilgang er, at man tager hæresiologernes (primært

10 B. A. Pearson, Gnosticism and Christianity in Roman and Coptic Egypt, Studies in Antiquity \& Christianity, T\&T Clark, London 2004, 201-223; jf. idem, Ancient Gnosticism. Traditions and Literature, Fortress, Minneapolis 2007, 8-12.52-100

11 Det drejer sig om Ninian Smarts velkendte religionstypologi fra Dimensions of the Sacred. An Anatomy of the World's Beliefs, University of California Press, Berkeley og Los Angeles 1996.

12 A. Marjanen, “'Gnosticisme'”, i: A. K. Petersen, J. Hyldahl og E. Thomassen (eds.), Mellem venner og fjender. En folkebog om Judasevangeliet, gnosis og tidlig kristendom, Antikken og kristendommen 6, Anis, København 2008, 183-206, 194f.

13 Se H. M. Schenke, “Das sethianische System nach Nag-Hammadi-Handschriften," i: P. Nagel, ed., Studia Coptica, Berliner byzantinistischer Arbeiten 45, Akademie, Berlin 1974, 165-173. 
Irenæus') afvisning af gnostikerne for pålydende og derigennem søger at rekonstruere en gruppe, som forstod sig selv som gnostikere. For både Schenke og Layton betød det en i forhold til megen gnosis-forskning stærkt indskrænket forståelse af, hvem 'gnostikerne' var. Tilbage bliver alene de sethianske tekster, mens fx valentinianske skrifter udelukkes fra kategorien gnostisk. En afgørende indvending over for denne opfattelse (se mere nedenfor) er, at den, når den kommer til de gnostiske tekster selv (og det vil i den her sammenhæng alene sige sethianske), står med det problem, at 'gnostisk' i ingen af teksterne bruges som selvbetegnelse. Hertil svarer Layton i en passage, som fortjener gengivelse, da den også reproduceres med billigelse af Brakke:

The answer lies in the fact that the name Gnostic was the name par excellence of the members of the hairesis [school of thought], their most proper name. As such, its function was not to convey information about what they were like, but rather to express their distinctiveness as a group; not to say what they were, but who they were. The claim to supply (or have) gnosis was absolutely banal, but the use of Gnostikos as a proper name was distinctive. Now, the works in the Gnostic mythographic corpus are pseudepigraphic and mythic in literary character, disguising their real author, audience, and place, date, and reason of composition. They do not speak of second- and third-century school controversies (as do the testimonia of Irenaeus, Porphyry, or Epiphanius), but rather of primordial, eschatological, and metaphysical events and relationships. In such compositions, there is no context in which a second-century school name such as Gnostikos might naturally occur. Thus, the absence of the proper name "Gnostikos" in the mythographic corpus is not a significant absence. ${ }^{14}$

Brakke er sig pinligt bevidst, at opfattelsens svageste punkt netop ligger i de 'gnostiske' teksters manglende brug af begrebet gnostiker som led i selvidentifikationen. Derfor uddyber han da også Laytons synspunkt gennem påstanden om, at de gnostiske skrifter i almindelighed skildrer den guddommelige sfæres struktur, skabelsen af universet og den første menneskerace, og at flertallet af dem hævder at hidrøre fra fortidens autoritative mytiske figurer som fx Adam, Zoroaster eller apostlen Johannes. Netop derfor kan man ikke forvente, hævder Brakke, at teksterne skulle bruge aktuelle kategorier fra det andet årh. e.v.t. (s. 47). For at få læseren til at forstå det griber han til to analogier. I forlængelse af et argument fremført af Birger Pearson hævder han, at heller ikke Qumran-skrifterne anvender betegnelsen essæere/essenere (s. 47) - det er imidlertid en dårlig sammenligning, al den stund man i Qumran-forskningen i disse år strides om relationen mellem Qumran-skrifter og Filons, Josefus' og Plinius' essæer/ essener-kategori, ligesom man i stigende grad har fået sans for, at de 'sekteriske' Qum-

14 B. Layton, "Prolegomena to the Study of Ancient Gnosticism," i: L. M. White, O. L. Yarbrough, eds., The Social World of the First Christians: Essays in Honor of Wayne A. Meeks, Fortress, Minneapolis 1995, 334-350, 344. Jf. B. Layton, The Gnostic Scriptures: A New Translation with Annotations and Introductions, Doubleday, Garden City, NY 1987, xxi-xxiii. 
ran-skrifter (yahad-teksterne) ikke repræsenterer én Qumran-gruppe, men beslægtede grupperinger. ${ }^{15}$ Hans andet eksempel er efter min mening heller ikke indlysende. Det stammer fra moderne evangelisk-luthersk kristendom, om hvilken Brakke hævder, at man, når man ser på deres kirkebygninger, næppe er i tvivl om, at de må være lutherske, ligesom et medlem fra menigheden direkte adspurgt om sig selv formentlig ville hævde, at hun/han var luthersk. Begrebet ville ifølge Brakke imidlertid næppe optræde i forbindelse med interne former for litteratur som fx prædikener, bibelkommentarer, søndagsskolemateriale (vi er i en amerikansk kontekst!), etc. (s. 48). Men spørgsmålet er, om ikke Brakke forregner sig. Som jeg husker det fra et år tilbragt i min ungdom i det amerikanske bibelbælte i North Dakota, var nogle af disse genrer faktisk fyldt med afgrænsninger til andre kristne konfessioner.

Det får være, hvad det er. Med det sidste punkt har jeg imidlertid begivet over til præsentationen af den bog, som har givet anledning til denne state of the art-artikel. Brakke har to formål med sin bog. For det første ønsker han i almindelighed at føre gnosis-drøftelsen videre gennem en uddybning af den forståelse, som hans lærer Bentley Layton har gjort sig til talsmand for (selvidentifikationstilgangen). ${ }^{16}$ For det andet ønsker han mere specifikt at bringe gnosis-forskningen videre gennem besindelse på den nye situation, som offentliggørelsen af Codex Tchachos og måske i særdelshed Judasevangeliet har givet anledning til. Han gør i sit forord selv opmærksom på, at det er hans bidrag om "Self-Differentiation among Christian Groups: The Gnostics and Their Opponents" til Margaret Mitchells og Frances Youngs første bind af Cambridge History of Christianity, ${ }^{17}$ som har været den direkte anledning til bogen (s. xi).

Lad det være sagt med det samme, at bogen er fremragende, uanset om man er enig med dens argumentation og konklusioner eller ej. Brakke skriver kort og koncist, men er netop derfor også i stand til at skære til benet og udelade al overflødig information og diskussion. Bogen består af fem kapitler foruden et kort noteapparat samt en udvalgt bibliografi over primærtekster i oversættelse. Dertil et indeks. Jeg havde gerne set en fuldstændig bibliografi, idet det i længden er trættende at orientere sig efter bibliografiske oplysninger, som skal stykkes sammen på grundlag af et noteapparat, det i sagens natur er vanskeligt at danne sig et overblik over. Jeg havde også gerne set større inddragelse af primærtekster; men da bogen i overvejende grad har karakter af en forskningsdiskussion, er det måske fornuftigt nok at indskrænke den til et 'udvidet essay'. Det er også lidt ejendommeligt, at bogen klinger ud uden en egentlig formalt markeret konklusion.

15 For en udmærket oversigtsartikel, se J. Taylor, "The Classical Sources on the Essenes and the Scrolls Communities", in: T. H. Lim \& J. J. Collins, eds., The Oxford Handbook of the Dead Sea Scrolls, Oxford UP, Oxford 2010, 173-199, se særligt s. 192f.

16 Se hertil A. Marjanen 2008, s. 189-191.

17 M. Mitchell \& F. Young, Cambridge History of Christianity. Origins to Constantine, Cambridge UP, Cambridge 2006. Se min review-artikel af bogen "Hvor står forskningen aktuelt i tidlig kristendom? State of the artartikel på baggrund af The Cambridge History of Christianity vol. 1", RvT 54 (2009), 85-95. 
Diskussionen i bogens fem kapitler er veldisponeret og skrider planmæssigt frem. I kap. 1 præsenterer Brakke den hidtidige forskningshistoriske drøftelse af emnet og lægger sig som beskrevet ovenfor i forlængelse af Bentley Laytons tilgang. Brakke afviser gnosticisme-kategorien gennem påstanden om, at den ikke udgør en synderlig brugbar religionshistorisk kategori, og, subsidiært, at den ikke betegner en eksisterende antik religion. Omvendt er han ikke lige så radikal som Williams eller King, fordi han samtidig argumenterer for, at der de facto var en gnostisk skole og at dennes tekster kan identificeres (s. x). Brakke hævder selv, at hans tilgang repræsenterer en middelvej mellem den traditionelle forståelse af 'gnosticisme' og den typologiske tilgang. Han er sig bevidst, at tilgangen ikke har haft så mange tilhængere hidtil, men anfører, at det skyldes, at 'selvidentifikationstilgangen' ofte forveksles med den typologiske. Brakke gør yderligere selv opmærksom på, at hans tilgang betyder en større åbenhed over for hæresiologernes værker, hvilket man som læser skal være opmærksom på, fordi det rører ved et mere principielt metodisk problem. I hvilken udstrækning kan man rekonstruere positioner ud fra deres modstanderes persiflerende og i en lang række tilfælde også stærkt misvisende gengivelser?

Kapitel 2 drejer sig naturligt om, hvordan det ud fra Brakkes forståelse er muligt at identificere gnostikerne og deres tekster. Meget programmatisk hævder Brakke, at enhver bestræbelse på at identificere gnostikerne i antikken må begynde med Irenæus (s. 29); men det er som nævnt ovenfor en mildest talt diskutabel pointe at identificere en gruppe eller grupper ud fra deres modstanderes synspunkter. Mod Brakke kan man også argumentere for, at så legitimt det end er at klassificere religiøse strømninger på grundlag af andenordensbegreber, lige så berettiget er det at kategorisere dem ud fra tredjeordensbegreber. Og der er i al fald analytisk ikke noget til hinder for at indføre en sondring mellem de to, altså en skelnen mellem gnosticisme og gnosis. Men der er også et andet problem i Brakkes forståelse.

Som Layton argumenterer han for, at gnostikerne skal findes i den strømning, som moderne forskning har betegnet sethiansk gnosis (s. 31). Ligesom Layton lægger Brakke også afgørende vægt på Johannesapokryfen som indbegreb af egentlig gnosis. Det er også i denne kontekst, at Brakke - trods opmærksomhed om vigtige forskelle til Johannesapokryfen og andre sethianske skrifter som Zostrianos, Den Fremmede og Zoroasters Bog - ender med at placere Judasevangeliet, som han også - igen trods opmærksomhed om væsentlige forskelle - identificerer med det Judasevangelium, Irenæus polemiserer imod (Adv. haer. 1.31.1). ${ }^{18}$ Som hos Layton kommer sethiansk gnosis hos Brakke til eksklusivt at identificeres med gnosis i den antikke verden, mens valentinianisme lades

18 Brakke følger i sin forståelse af Judasevangeliet den opfattelse, som efterhånden har sat sig igennem i fortolkningen af teksten, nemlig at Judas fremstår som en i bedste fald tvetydig figur og i værste fald negativ skikkelse (s. 38). Vi er langt fra de første udgiveres positive forståelse af Judasfiguren, som også har været bragt til torvs af enkelte danske eksegeter, se fx J. T. Nielsen, “Jesu lidelse på godt og ondt; Judasevangeliets populære polemik", Bibliana 8 (1), 2007, 24-30. For Judas' rolle i evangeliet, se min artikel "The Gospel of Judas: A Scriptural Amplification or Canonical Encroachment?", in: G. Wurst \& E. Popkes, eds., Judasevangelium and Codex Tchachos, Mohr-Siebeck, Tübingen 2012 (under udgivelse). 
ude af betragtning, fordi det betragtes som en senere kristianisering af gnosis (jf. Irenæus Adv. haer. 1.11.1). Dermed har Brakke fået identificeret en gnostisk tankestrømning (school of thought), hvis myte og ritualer han kan fremstille i bogens tredje kapitel. Som Layton lider Brakke efter min mening af den vrangforestilling, at man analytisk alene kan operere med religioner eller, måske mere præcist, religiøse strømninger under den forudsætning, at de lader sig identificere som sociale grupper. Det er en meget indskrænket opfattelse, som for det første ikke tager højde for, at flere religioner eller religiøse strømninger har vi alene adgang til som diskursive formationer. Vi ved ganske enkelt ikke noget om den/de grupper, der stod bag teksterne. Pythagoræisme er et tankevækkende eksempel. ${ }^{19}$ For det andet er det en misforståelse at tro, at blot fordi en religion alene lader sig uddestillere gennem en tekstuel semiotisering, kan den ikke have klangbund i virkeligheden. Et meget væsentligt udtryk for religion er netop religionens manifestation som diskursiv formation i skikkelse af tekster. Jeg synes, at Brakkes opfattelse her lider under nogle grundlæggende videnskabsfilosofiske uklarheder.

En væsentlig religionshistorisk pointe vedrører gnosticismens oprindelse. I et opgør med ikke mindst Bousset-, Reitzenstein- og senere Jonas- og Bultmannskolens forståelse af gnosis ud fra tanken om en orientalsk myte om urmennesket og frelseren, der selv skulle forløses (salvator salvandus), og som via hellenismen var kommet ind i den kristne gnosis, ${ }^{20}$ har forfægtere af sethiansk gnosis som central i udviklingen af gnosis fremhævet gnosticismens før-kristne jødiske baggrund. ${ }^{21}$ Som Layton er Brakke imidlertid af den opfattelse, at gnosis skal forstås som et helt igennem kristent fænomen (se navnlig s. 84-86).

I kap. 3 gælder det på grundlag af navnlig Johannesapokryfen og delvist Judasevangeliet, Zostrianos og Den Fremmede om først at skildre Gud og den guddommelige sfære. Siden følger underafsnit om hhv. materien, bibelsk historie og muligheden for gnosis og et om gnostikerne og andre kristne, inden Brakke i et yderligere underafsnit går over til at drøfte dåb og mystisk opstigen som gnostiske ritualer. I det

19 Jeg skylder ikke mindst min kollega lektor, dr. phil. Jeppe Sinding Jensen denne pointering. Jeg er Jeppe Sinding Jensen stor tak skyldig for mange samtaler gennem årene omkring basale videnskabsfilosofiske og videnskabsteoretiske emner.

20 En forestilling, som historisk hviler på et meget spinkelt tekstgrundlag al den stund de tekster, som har været brugt til at rekonstruere myten, stammer fra en væsentlig senere tid, ligesom rekonstruktionen forudsætter en tvivlsom sammenstilling at tekstelementer taget ud af vidt forskellige sammenhænge. Denne type gnosis-forskning gjorde allerede Carsten Colpe en gang for alle op med i sin banebrydende bog Die Religionsgeschichtliche Schule. Darstellung und Kritik vom gnostischen Erlösermythus, FRLANT 78, Vandenhoeck \& Ruprecht, Göttingen 1961. Colpes bog var samtidig et grundlæggende opgør med den noget vidløftige form for parallelomani, som trivedes i den foudgående traditions jagt på ligheder på tværs af religionerne. Se hertil også S. Sandmel, “Parallomania”, Journal of Biblical Literature 81, 1962, 1-13.

21 Det gælder fx Williams 1996, s. 218, og Pearson 2004, s. 26-28. Se også J. D. Turner, Sethian Gnosticism and the Platonic Tradition, Bibliothèque copte de Nag Hammadi, Études 6, Peeters, Louvain 2001, 4f, og samme, "The Setting of the Platonizing Sethian Treatises in Middle Platonism", in: J. D. Turner \& R. Majercik, eds., Gnosticism and Later Platonism. Themes, Figures, and Texts, SBL SR 12, Atlanta 2000, 179-224, 179, som ikke mindst har peget på sammenhængen mellem sethiansk gnosis, platonisme og hellenistisk jødedom. 
afsluttende underafsnit om oprindelsen og karakteren af den gnostiske tankestrømning sammenfatter Brakke sin forståelse ud fra det rekonstruerede gnostiske forestillingssystem af myter og ritualer. Det er her, han mest tydeligt i bogen argumenterer for, at gnostikerne i løbet af det andet århundrede kom til at udgøre en distinkt gruppe, og at de hidrørte fra en specifik kristen sethiansk sammenhæng, som i stigende grad gennem påvirkning fra platonisme differentierede sig fra andre mere mainstream-former for kristendom (s. 87).

Bogens fjerde kapitel retter meget naturligt fokus mod spørgsmålet om enhed og mangfoldighed i det andet århundredes Rom. Brakke diskuterer blandt andet her en i forhold til hans gnosis-definition række beslægtede fænomener som Markion og valentinianisme. Billedet komplementeres af Justin, som i stort set samme periode omkring 150 befandt sig i Rom. Justin er interessant, fordi han inden for den strømning, som senere blev socialt institutionaliseret og dogmatisk kanoniseret som mainstreamkristendom,22 bidrog stærkt til dannelsen af en egentlig kætterkategori. Fra oprindeligt at være et neutralt begreb, som betegnede et bestemt område som fx medicin, en retning inden for en filosofisk skoledannelse med fælles forpligtethed på bestemte værdier eller troskab mod en bestemt lærer eller slet og ret en gruppe i almindelighed, kom hairesis (hæresi) i løbet af det andet århundrede til at stå for afvigende grupper med afvigende doktrinært indhold (s. 106). I forlængelse af Paulus' tale om splittelser og partidannelser (jf. 1 Kor 11,18f; Gal 5, 19f) og en i dag ukendt Jesusprofeti om, at endetiden ville være kendetegnet af splittelser og fraktionalisme (se Justin Dial. 35.3), bidrager Justin stærkt til at skabe forestillingen om, at kristne grupper, som afviger fra hans forståelse af kristendom, netop ikke repræsenterer kristendom, men i stedet for deres egne afvigende synspunkter som hhv. markionitisk eller valentiniansk hairesis, dvs. idiosynkratiske kætterier (Dial. 35.4f). Det samme gælder imidlertid eo ipso den anden vej rundt $\mathrm{i}$ forholdet mellem valentinianske former for gnosis og fx Justins kristendom. Men det er en vanskelig situation at drage grænser i en kontekst, hvor de andre ligner en selv. Det gælder her, hvad Irenæus klart indser: "Herren har befalet os at vogte os for dem, som taler ting lig os, men som tænker forskelligt" (Adv. haer. 1.fortalen.2). ${ }^{23}$

22 Det er indholdsmæssigt allerede problematisk at gøre Justin til en slags embryonal mainstream-kristendom eller til repræsentant for det, der ligeledes anakronistisk misvisende undertiden betegnes proto-ortodoksi. Det er alene som tilbageprojektion, det er meningsfuldt, og selv her er der problemer, fordi tanken forudsætter en direkte indholdsmæssig kontinuitet, som dårligt lader sig opretholde. Det er efter min mening alene i kraft af en bestemt font af tegn og betydningsstrukturer, hvor man i forholdet mellem Justin og senere former for kristen ortodoksi kan tale om en større genkendelighed, end der fx råder i relationen mellem valentiniansk gnosis og senere ortodokse typer af kristendom. Sprogligt er det imidlertid uhyre vanskeligt at endegyldigt løsive sig fra en organisk model, som næsten tvinger en til at konceptualisere Justins, Irenæus', Tertullians, etc.'s forskellige versioner af kristendom som samme fænomen samt, subsidiært, at opfatte dem som forløbere for knæsættelsen af en egentlig kristen ortodoksi i løbet af de sidste tre fjerdedel af det fjerde århundrede.

23 Se hertil de indledende teoretiske overvejelser i min kommende artikel "Othering in Paul. A Case-Study of 2 Corinthians", in: M. Kahlos, ed., The Faces of the Other: Religious Rivalry and Ethnic Encounters in the Later Roman World, Cursor Mundi 10, Brepols, Turnhout 2012. 
Bogens afsluttende kapitel fokuserer på selvdifferentieringsstrategier. Her har Brakke et skarpt blik for, hvordan kristne på tværs af sted og trods betydelige grader af forskellighed ideologisk var med til at rendyrke en (metaforisk) næsten naturlig forestilling om kristen ensartethed. Trods splittelser og stridigheder kom enhedstanken til ideologisk at spille en afgørende rolle og bidrog derved til også på det sociale niveau at bekæmpe centrifugale tendenser gennem en nærmest retorisk ideologisk besværgelse af centripetalitet: "Jeg, der er fange for Herrens skyld, formaner jer da til at leve, så det svarer til det kald, I fik, med al ydmyghed og mildhed, med tålmodighed, så I bærer over med hinanden i kærlighed og stræber efter at fastholde Åndens enhed med fredens bånd: ét legeme og én ånd, ligesom I jo også blev kaldet til ét håb; én Herre, én tro, én dåb; én Gud og alles fader, som er over alle, gennem alle og i alle" (Ef 4, 1-6).

Gennem sådan retorik har kristendommen været stærkt medvirkende til at skabe forestillingen om den ene, hellige apostolske kirke, der også har haft betydelig gennemslagskraft i forskningen. Brakke nævner selv en indflydelsesrig artikel af George MacRae "Why the Church Rejected Gnosticism?", som ved sin titel afslører, hvordan forfatteren og med ham en hel forskningstradition har abonneret på en stærk forestilling om kirken som monolitisk enhed. ${ }^{24}$ Men hvad nu hvis 'kirke' og 'gnosis' i udgangspunktet ikke var adskilte størrelser, men alene blev det i kraft af nogle bestemte diskursiveringer, som hjulpet af øget institutionel rygdækning i stigende grad fik social gennemslagskraft i løbet af det tredje århundrede og endnu mere, når vi når frem til midten af det fjerde århundrede, hvor kejsermagt og kirke (fra 320) også i stigende grad blev smedet i hymens lænker? Dertil kommer, som Brakke fint gør opmærksom på, at der ikke blot var tale om afvisning af den ene part hos den anden og omvendt (s. 113). Det historiske billede var betydelig mere komplekst; for som Brakke fremhæver var der en betydelig variation af kristne grupper, som løbende forhandlede deres relationer med andre, både kristne og ikke-kristne grupper (ibid). Det er disse forhandlingsstrategier, som står i centrum af kapitlet, hvor Brakke har udtalt sans for ligheder på tværs af grupperinger, som forstår hinanden som hinandens radikale andethed.

I løbet af det tredje århundrede er der imidlertid meget, som tyder på, at den institutionalisering, som gælder, hvad der i det fjerde århundrede sætter sig igennem som mainstream-kristendom, også har paralleller i markionisme og valentinianisme: "Evidence suggests that during the third century and later, Valentinian Christianity increasingly took on the character of a fully independent network of churches, similar to that of the Marcionites" (s. 119). Det er disse selvstændige institutionaliseringsprocesser, som ad åre førte til, at de forskellige grupper på et tidspunkt kommer til at fremstå som selvstændige grupperinger og religiøse strømninger; men igen er det væsentligt at pointere, at det er de ikke i den første lange del af deres tilblivelsesfase. Det er primært et sent tredje århundredes og i særdeleshed et fjerde århundredes fænomen.

24 G. W. MacRae, "Why the Church Rejected Gnosticism”, in: idem, Studies in the New Testament and Gnosticism, Good New Studies 26, Glazier, Wilmington 1987, 251-62. 
Lidt overraskende i forhold til de forudgående kapitlers fokus på sethiansk gnosis vælger Brakke i det afsluttende kapitel at koncentrere sig om valentinianisme, fordi valentinianerne i særlig grad for Irenæus fremstod som den største trussel mod dennes egen kristendom (s. 120). På ny gælder, at hvad der i den lokale kontekst tager sig ud som kategorialt forskellige størrelser, set fra Mars fremstår som to alen af samme stykke:25 "Moreover, Irenaeus' own thought did not differ as fundamentally from the teachings of the Gnostics and the Valentinians as he would have liked his readers to think" (s. 124). En mulig grund til at Brakke her primært retter opmærksomheden mod valentinianerne, er, at når det gælder betydningen af læreren og den rolle, han tilskrives for sikringen af autenciteten og ægtheden i den kristne overlevering, ligner valentinianere igen Irenæus, Klemens af Alexandria og Origenes. Der er ikke stor forskel på dem (s. 115). I højere grad end sethianske gnostikere repræsenterer valentinianerne for Brakke en kristendomstype, som har været igennem en kristianisering meget lig den, vi finder hos dem, som vi traditionelt kender med den i en historievidenskabelig sammenhæng problematiske dogmatiserende og naturaliseringsfunderende betegnelse 'kirkefædrene' (hvorved man sprogligt i en historievidenskabelig sammenhæng har bidraget til at sanktionere og essentialisere en bestemt kristendomstype som 'kirkens' fundament uden besindelse på, at der på dette tidspunkt ikke var nogen 'kirke' i den ligefremme monolitiske forstand, ligesom der heller ikke var 'fædre' og 'kættere').

Det skulle gerne stå klart, hvorfor alle med interesse for klassisk religionshistorie, hvor gnosis-forskningen traditionelt har spillet en vigtig rolle, tidlig jødedom, kristendom og gnosticisme, bør læse Brakkes bog. Den er religionshistorisk og religionsvidenskabelig uomgængelig. Jeg håber også med denne review-artikel at have tegnet nogle af de vægtigste konturer i den nyeste gnosis-forskning. Ikke overraskende er området i dag noget mere komplekst, end det fx var under min studietid for 20 år siden, hvor det var Bianchis og Rudolphs forståelser, der blev henvist til, når man skulle kende status quaestionis inden for gnosis-forskningen. Man kan ikke længere pege på en samlet forståelse. Dertil er uenighederne og retningerne inden for moderne forskning for store. Omvendt er det, som jeg har forsøgt at vise her, muligt at pege på nogle overordnede linjer. Skal jeg afslutningsvis pege på et punkt, hvor jeg tror, Brakkes bog vil være repræsentativ for udviklingen i de kommende år, er det revitaliseringen af selve gnosis-kategorien. William's og i særlig grad Kings radikale begrebselimination løser ikke de problemer, vi står over for. Bagudskuende forekommer det også en anelse filosofisk troskyldigt, fordi emic og etic perspektiver sammenblandes, ligesom navnlig

25 Albert Baumgarten har i artiklen "The Rule of the Martian as Applied to Qumran", Israel Oriental Studies 14, 1994, s. 121-42 introduceret begrebet 'marsmandens regel' som udtryk for det velkendte sociologiske forhold, at den gruppe, man retorisk og ideologisk bruger flest kræfter på at etablere et kategorialt modsætningsforhold til, som oftest er den gruppe, der ligner ens egen mest. Hvad der i den lokale kontekst tager sig ud som en milevid forskel, fremstår i marsmandens perspektiv som lighed. Det er en afgørende pointe, fordi man i megen forskning ofte har taget teksternes othering for pålydende og med teksterne fremhævet forskelle, hvor der hyppigt er tale om en høj grad af ideologisk sammenfald. Det gælder fx Jesusgruppens forhold til farisæerne. 
Kings opfattelse er udtryk for en manglende besindelse på forskellen mellem fænomen og begreb. Personligt vil jeg foretrække en etic-funderet gnosis-definition, fordi jeg som sagt stiller mig skeptisk over for Laytons og Brakkes emic funderede forsøg på eksklusivt at identificere sethiansk gnosis med egentlig gnosis. Opererer man i stedet med en etic-baseret forståelse (gnosticisme), er vejen banet for at se valentinianisme og sethianisme som forskellige manifestationer af samme fænomen, som samtidig har en række beslægtede fænomener i det, vi vanligvis har identificeret med mainstream-kristendom. Noget af det mest spændende i den nye gnosis-forskning er forståelsen af, i hvor høj grad gnostiske typer af kristendom med lige så megen hjemmel i deres udlægning kunne påberåbe sig nytestamentlige forfattere som Paulus og Johannes-evangeliet som dem, vi under normale omstændigheder identificerer med kristendom. Her ligger virkelig en udfordring til at tænke nyt, fordi en sådan besindelse på de gnostiske forfatteres klangbund i nytestamentlige skrifter skulle modvirke den form for genealogisk og dogmatiserende vanetænkning, som vi kender alt for godt: Linjen der trækkes fra Ny Testamente over de apostolske fædre til de senere kristne hæresiologer og apologeter som Justin, Irenæus og Tertullian. Jo mere man får sans for problemerne i den genealogisk organiske model, desto større bliver behovet også for nykonceptualiseringer, som forsøger at vriste sig fri af organisk monolitisk tænkning. Også i den sammenhæng er Brakkes bog fortrinlig at lade sig udfordre af, hvis man annammer den skænkede viden.

Anders Klostergaard Petersen, professor MSO, cand.theol. Religionsvidenskab, Institut for Kultur og Samfund Aarhus Universitet 